Jurnal Mandala Pharmacon Indonesia, Vol 6.No.2 Desember 2020

Avaiable online at www.jurnal-pharmaconmw.com/jmpi

p-ISSN : 2442-6032

$e$-ISSN : 2598-9979

\title{
Optimasi Konsentrasi Sukrosa Terhadap Transparansi Dan Sifat Fisik Sabun Padat Transparan Minyak Atsiri Sereh Wangi (Cymbopogon citratus L.)
}

La Ode Muhammad Andi Zulbayu, Risky Juliansyah, Firawati

Program Studi Farmasi, STIKES Mandala Waluya Kendari

\begin{abstract}
ABSTRAK
Sereh wangi (Cymbopogon citatus L.) merupakan tanaman rempah yang sangat bermanfaat dalam bidang kesehatan. Minyak atsiri daun sereh bersifat sebagai anti jamur dan antibakteri. Banyak khasiat serta manfaat yang dimiliki oleh herba sereh wangi, hal ini memberikan peluang untuk digunakan pada pembuatan beberapa bentuk sediaan farmasi untuk meningkatkan nilai tambah tanaman tersebut. Pemanfaatan yang dapat digunakan seperti dibuat dalam bentuk formulasi sediaan sabun transparan. Sukrosa memiliki fungsi untuk membantu terbentuknya transparansi pada sabun. Penelitian ini bertujuan untuk melakukan optimasi terhadap penggunaan sukrosa dalam formulasi untuk memperoleh tingkat transparansi yang baik serta untuk mengetahui kestabilan fisik sabun padat transparan. Sabun transparan minyak atsiri sereh wangi divariasi dengan penggunaan konsentrasi sukrosa 11\% (Formula A), 13\% (Formula B) dan $15 \%$ (Formula C). Sabun yang dihasilkan dilakukan pengujian meliputi organoleptik, $\mathrm{pH}$,
\end{abstract}

homogenitas, tinggi busa dan transparansi. Hasil yang diperoleh bahwa tingkat transparansi sediaan sabun padat transparan dipengaruhi oleh konsentrasi sukrosa yang digunakan dalam formula. Konsentrasi sukrosa yang optimum untuk memperoleh transparansi yang baik yaitu 15 \% (Formula C). Pengujian stabilitas fisik meliputi nilai $\mathrm{pH}$, stabilitas tinggi busa dan homogenitas menunjukkan tidak ada perubahan yang siginifikan selama pengujian empat minggu. Hal ini membuktikan bahwa sediaan sabun padat transparan minyak atsiri sereh wangi stabil secara fisik.

Kata kunci : Minyak atsiri sereh wangi, sukrosa, sabun padat transparan, stabilitas fisik.

\section{Penulis Korespondensi :}

La Ode Muhammad Andi Zulbayu

Program Studi Farmasi, STIKES Mandala Waluya Kendari

E-mail : anzulwatonea@gmail.com

\section{PENDAHULUAN}

Sabun sebagai salah satu pembersih tubuh yang digunakan oleh masyarakat dan berfungsi membantu membersihkan kotoran pada kulit, termasuk keringat dan juga sisa kosmetik. Penggunaan sabun untuk membersihkan kulit semakin meningkat dan beragam dikalangan masyarakat. Sediaan sabun secara umum terbagi menjadi 2 jenis seperti sabun berbentuk padatan dan sabun berbentuk cairan. Jenis-jenis sabun padat adalah sabun opaq, transclucent dan sabun transparan (Priani \& Lukmayani, 2010). Penggunaan sabun dengan kandungan bahan kimia pada kulit dapat mengurangi bahkan menghilangkan fungsi barrier kulit untuk menjaganya kelembaban yang dapat menyebabkan kulit menjadi kering dan memicu terjadinya iritasi (Setyoningrum, 2010).

Dalam hal mencegah timbulnya masalah kulit tersebut, yang dapat dilakukan yaitu menggunakan sabun transparan biasa disebut sabun gliserin. Keuntungan dari sabun transparan adalah dapat menghasilkan busa yang lembut, memberikan penampakan yang 
menarik dan berkilau serta melembabkan kulit. Beberapa faktor yang mempengaruhi proses pembentukan transparansi sabun adalah alkohol, gliserin serta yang paling berperan penting dalam pembentukan transparasi adalah gula (sukrosa) (R. Pratiwi \& Andiyani, 2014).

Sukrosa dalam sabun transparan memiliki fungsi sebagai agen pembentuk transparensi untuk meningkatkan nilai estetika sabun. Selain itu juga berperan sebagai humektan untuk menjaga kelembaban kulit (Hardian et al., 2014). Pada penelitian tentang formulasi sabun ekstrak pegagan dengan menunjukkan penambahan sukrosa meningkatkan transparansi sediaan sabun (Sasongko \& Mumpuni, 2017). Tujuan utama pembuatan sabun padat transparan sebagai pembersih kulit bukan hanya untuk membuatnya menarik dari segi penampilan tetapi aspek manfaat juga perlu dipertimbangkan, oleh karena itu dalam pembuatan sabun transparan dibutuhkan zat aktif yang mampu memberikan manfaat (Priani \& Lukmayani, 2010).

Sereh wangi (Cymbopogon citratus L) merupakan salah satu tanaman yang bisa dimanfaatkan sebagai antibakteri. Sereh wangi (Cymbopogon citratus L) merupakan tanaman rempah dengan banyak bermanfaat dalam bidang kesehatan. Salah satu pemanfaatan tanaman sereh wangi sebagai obat dalam bentuk minyak atsiri. Minyak atsiri sereh memiliki kandungan sitronelal 32\% sampai $45 \%$ memiliki khasiat mengobati gatal dan jerawat pada kulit (Bota et al., 2015). Pada penelitian lain menjelaskan sediaan sabun padat minyak atsiri sereh wangi mempunyai potensi sebagai antibakteri terhadap bakteri Staphylococcus aureus dengan konsentrasi 5\%. Melihat potensi antibakteri yang dimiliki minyak atsiri daun sereh dapat membantu meningkatkan nilai guna dari sabun tersebut (Rita et al., 2018).

Dari uraian diatas, hal inilah yang menjadi acuan untuk membuat formulasi sediaan sabun padat transparan minyak atsiri sereh wangi bertujuan melakukan optimasi terhadap penggunaan sukrosa dalam formulasi untuk memperoleh tingkat transparansi yang baik serta untuk mengetahui kestabilan fisik sabun padat transparan tersebut.

\section{METODE PENELITIAN}

Alat

Alat yang digunakan adalah gelas kimia (Pyrex $\left.{ }^{\circledR}\right)$, cawan krusibel, cawan porselin $\left(\right.$ Pyrex $\left.^{\circledR}\right)$, cetakan sabun, gegep kayu, gelas ukur $\left(\right.$ Pyrex $\left.^{\circledR}\right)$, hot plate (Yenaco ${ }^{\circledR}$ ), thermometer, batang pengaduk, timbangan analitik (Yenaco ${ }^{\circledR}$ ), pipet tetes (Caramel_styleo2 $\left.{ }^{\circledR}\right), \quad \mathrm{pH}$ universal (Mquant ${ }^{\circledR}$ ).

\section{Bahan}

Bahan yang digunakan adalah asam stearat, aquadest, DEA, etanol 96\%, gliserin, sukrosa, minyak atsiri daun sereh wangi, minyak jarak, $\mathrm{NaOH}$ dan $\mathrm{NaCl}$.

\section{Prosedur Kerja}

\section{Ekstraksi Sereh Wangi dengan Metode destilasi}

Ditimbang sereh wangi sejumlah 10 kg. Selanjutnya dimasukkan pada wadah destilasi. Air ditambahkan ke dalam wadah sampai sampel tenggelam. Pemanasan dilakukan menggunakan api kecil. Uap panas dari pemanasan dialirkan melalui pipa kondensor. Selanjutnya separator akan menampung filtrat dan air hasil kondensasi. Untuk memisahkan air dan minyak digunakan kain monel (Rita et al., 2018).

\section{Formulasi sediaan sabun padat} transparan minyak sereh wangi

Semua bahan yang digunakan ditimbang terlebih dahulu. Dipanaskan asam stearat pada suhu $60^{\circ} \mathrm{C}$ selama 15 
menit. Ditambahkan minyak jarak kemudian diaduk hingga homogen. Diukur suhu hingga mencapai $70^{\circ} \mathrm{C}$ $80^{\circ} \mathrm{C}$ setelah itu dimasukkan $\mathrm{NaOH}$. Pengadukan dilakukan sekitar 3-5 menit sampai masa sabun terbentuk. Ditambahkan gliserin, etanol, gula pasir, DEA, $\mathrm{NaCl}$, dan aquadest hingga terbentuk sabun dasar. Ditambahkan minyak atsiri sereh wangi kemudian diaduk hingga benar-benar homogen sekitar 7-10 menit. Dituangkan campuran kedalam cetakan dan didiamkan selama 24 jam sehingga sabun mengeras (Hernani et al., 2010). Sediaan dibuat 3 formula yaitu Formula A, B dan C dengan 3 replikasi dengan memlakukan variasi konsentrasi sukrosa seperti pada tabel 1 berikut.

Tabel 1. Formulasi sabun padat transparam minyak sereh wangi (Cymbopogon citratus L)

\begin{tabular}{clccc}
\hline No & Nama Bahan & Formula 1 & Formula 2 & Formula 3 \\
\hline $\mathbf{1}$ & $\begin{array}{l}\text { Minyak atsiri } \\
\text { sereh wangi }\end{array}$ & $5 \%$ & $5 \%$ & $5 \%$ \\
\hline 2 & Minyak Jarak & $20 \%$ & $20 \%$ & $20 \%$ \\
\hline 3 & NaOH & $20 \%$ & $20 \%$ & $20 \%$ \\
\hline $\mathbf{4}$ & Asam stearat & $6,5 \%$ & $6,5 \%$ & $6,5 \%$ \\
\hline $\mathbf{5}$ & Gliserin & $13 \%$ & $13 \%$ & $13 \%$ \\
\hline $\mathbf{6}$ & Etanol & $16 \%$ & $16 \%$ & $16 \%$ \\
\hline 7 & Sukrosa & $11 \%$ & $13 \%$ & $15 \%$ \\
\hline $\mathbf{8}$ & DEA & $3 \%$ & $3 \%$ & $3 \%$ \\
\hline $\mathbf{9}$ & NaCl & $0,2 \%$ & $0,2 \%$ & $0,2 \%$ \\
\hline $\mathbf{1 0}$ & Aquadest & Ad 100 \% & Ad 100 \% & Ad 100 \% \\
\hline
\end{tabular}

\section{Uji organoleptik}

Pengujian organoleptik bertujuan mendeskripsikan sediaan dari bentuk fisik melalui pengamatan warna, aroma dan bentuk sediaan. Pada pengujian organoleptik dilakukan pengujian secara personal untuk menilai warna, aroma dan melihat bentuk sabun padat transparan (Riyanta \& Nurniswati, 2016).

\section{Uji pH}

Pengujian $\mathrm{pH}$ menggunakan $\mathrm{pH}$ universal terhadap sampel yang telah dilarutkan. Larutan sampel dilarutkan sebanyak 0,1 gram dalam $10 \mathrm{ml}$ aquadest untuk masing - masing formula dilakukan 3 kali replikasi (Riyanta \& Nurniswati, 2016).

\section{Uji tinggi busa}

Pengukuran

tinggi busa menggunakan metode sederhana. Sampel ditimbang sebanyak 1 gram. Digunakan gelas ukur $25 \mathrm{~mL}$ untuk melarutkan sampel dengan $10 \mathrm{~mL}$ aquadest. Gelas ukur dikocok dengan cara dibolak-balik. Pengamatan ketinggian busa dilakukan 5 menit kemudian. (Septiani et al., 2011).

\section{Uji homogenitas}

Masing - masing sediaan dari tiap formulasi sediaan sabun mandi transparan yang dibuat dari minyak sereh sebagai bahan aktif dengan variasi konsentrasi sukrosa, pemeriksaan homogenitas dilakukan dengan cara melihat secara kasat mata bentuk dan transparansi sabun (Septiani et al., 2011).

\section{Uji transparansi sabun}

Uji transparansi sabuk menggunakan metode sederhana. Sabun transparan dengan tebal 0,25 inci atau o,635 bm) diletakkan diatas kertas yang telah memiliki tulisan tipe Times New Roman dengan besar font 14. Pengukuran 
dilakukan untuk setiap formula sebanyak 3 kali replikasi (F. N. Pratiwi, 2015).

\section{HASIL DAN PEMBAHASAN}

Pada penelitian ini dibuat sediaan sabun padat transparan menggunakan zat aktif minyak atsiri sereh wangi. Sabun padat transparan dibuat menjadi 3 formula dengan variasi konsentrasi sukrosa untuk memperoleh tingkat transparansi yang baik. Formula yang dibuat adalah Formula A mengandung sukrosa 11\%, Fomula B mengandung sukrosa $13 \%$ dan Formula C mengandung sukrosa $15 \%$. Penggunaan variasi konsentrasi sukrosa tersebut untuk memperoleh sediaan sabun transparan dengan tingkat transparansi yang baik.

Tabel 2. Organoleptik sabun padat transparan minyak sereh wangi

\begin{tabular}{|c|c|c|c|c|}
\hline \multirow{2}{*}{ Minggu ke } & \multirow{2}{*}{ Formula } & \multicolumn{3}{|c|}{ Parameter Organoleptik } \\
\hline & & Warna & Aroma & Bentuk \\
\hline \multirow{3}{*}{ I } & $\mathrm{A}$ & Kuning pucat & Bau khas sereh & Padat \\
\hline & B & Kuning & Bau khas sereh & Padat \\
\hline & $\mathrm{C}$ & Kuning cerah & Bau khas sereh & Padat \\
\hline \multirow{3}{*}{ II } & $\mathrm{A}$ & Kuning pucat & Bau khas sereh & Padat \\
\hline & B & Kuning & Bau khas sereh & Padat \\
\hline & $\mathrm{C}$ & Kuning cerah & Bau khas sereh & Padat \\
\hline \multirow{3}{*}{ III } & $\mathrm{A}$ & Kuning pucat & Bau khas sereh & Padat \\
\hline & B & Kuning & Bau khas sereh & Padat \\
\hline & $\mathrm{C}$ & Kuning cerah & Bau khas sereh & Padat \\
\hline \multirow{3}{*}{ IV } & A & Kuning pucat & Bau khas sereh & Padat \\
\hline & B & Kuning & Bau khas sereh & Padat \\
\hline & $\mathrm{C}$ & Kuning cerah & Bau khas sereh & Padat \\
\hline
\end{tabular}

Keterangan :

A = Sabun padat transparan dengan penambahan sukrosa $11 \%$

$\mathrm{B}=$ Sabun padat transparan dengan penambahan sukrosa $13 \%$

$\mathrm{C}=$ Sabun padat transparan dengan penambahan sukrosa $15 \%$

Pengujan organoleptik ini bertujuan untuk mengukur tingkat pemenuhan aspek yang dapat diterima (acceptability) oleh masyarakat selaku konsumen. Berdasarkan tabel 2 menunjukkan bahwa sediaan sabun transparan minyak sereh wangi dari formula yaitu $\mathrm{A}, \mathrm{B}$, dan $\mathrm{C}$ memiliki bentuk padat serta aroma khas dari minyak sereh wangi. Warna Formula A yaitu kuning pucat, Formula B berwarna Kuning dan Formula $\mathrm{C}$ berwarna kuning cerah. Hal ini terjadi akibat perbedaan konsentrasi sukrosa yang digunakan. Dari hasil pengujian menunjukkan tidak ada perbedaan pengujian minggu pertama sampai minggu keempat.

Pada pengujian homogenitas diperoleh bahwa Formula A, B dan C sudah homogen. Hal ini dilihat dari penampakan tidak adanya butiranbutiran kasar ataupun partikel pada permukaan sabun transparan selama empat minggu. Perbedaan konsentrasi sukrosa tidak mempengaruhi hasil uji homogenitas sabun padat transparan minyak sereh wangi.

Hasil pengujian pH seperti tabel 3 pada minggu pertama dan minggu kedua formula A, formula $\mathrm{B}$ dan formula $\mathrm{C}$ memiliki pH sekitar 9, sedangkan pada 
minggu ketiga dan keempat ketiga formula memiliki $\mathrm{pH}$ sekitar 10. Nilai $\mathrm{pH}$ yang ditunjukkan oleh setiap formula tersebut memiliki range $\mathrm{pH}$ sesuai dengan pH sabun sekitar 9-11. Rentang $\mathrm{pH}$ tersebut masih dalam rentang yang relatif aman bagi kulit (Setyoningrum, 2010).

Tabel 3. Pengujian pH sabun transparan minyak daun sereh

\begin{tabular}{ccccc}
\hline \multirow{2}{*}{ Formula } & \multicolumn{4}{c}{ Minggu ke- } \\
\cline { 2 - 5 } & I & II & III & IV \\
\hline A & 9 & 9 & 10 & 10 \\
\hline B & 9 & 9 & 10 & 10 \\
\hline C & 9 & 9 & 10 & 10 \\
\hline
\end{tabular}

Keterangan :

$\mathrm{A}=$ Sabun padat transparan dengan penambahan sukrosa $11 \%$

$\mathrm{B}=$ Sabun padat transparan dengan penambahan sukrosa $13 \%$

$\mathrm{C}=$ Sabun padat transparan dengan penambahan sukrosa $15 \%$

Secara umum sabun dikatakan sabuk yang baik jika memiliki busa yang banyak. Namun kenyataannya banyaknya busa tidak selalu berbanding lurus dengan

kemampuan

dalam membersihkan kotoran. Pengujian tinggi busa formula A, formula B dan formula C dilakukan selama empat minggu menujukkan hasil ketinggian busa adalah $9 \mathrm{~cm}$. Selama empat minggu tidak terjadi perubahan, hal ini menunjukkan bahwa ketiga formula sabun padat transparan minyak sereh wangi memiliki ketinggian busa yang stabil.

Pada pengujian transparasi sabun padat transparan dilakukan dari minggu pertama hingga minggu keempat pada Formula A,B dan $\mathrm{C}$ diperoleh hasil bahwa ketiga formula tersebut memiliki penampakan yang transparan. Sabun dikatakan telah memenuhi kriteria transparansi jika tulisan atau huruf dengan ukuran 14 terlihat melalui sabun padat transparan yang memiliki ketebalan 0,25 inci atau $0,635 \mathrm{~cm}$ (R. Pratiwi \& Andiyani, 2014). Hasil pengujian transparansi seperti pada gambar 1 berikut.

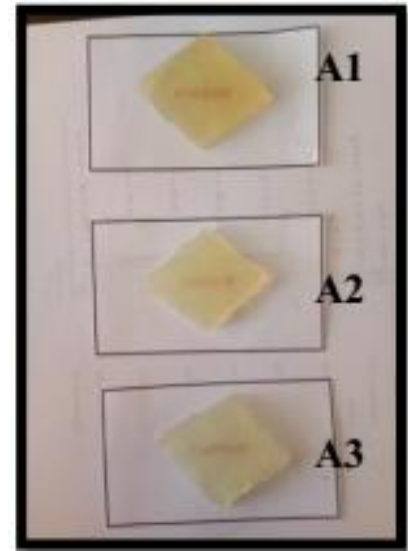

Formula A

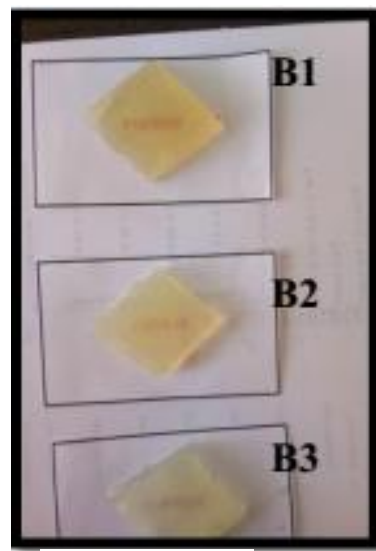

Formula B

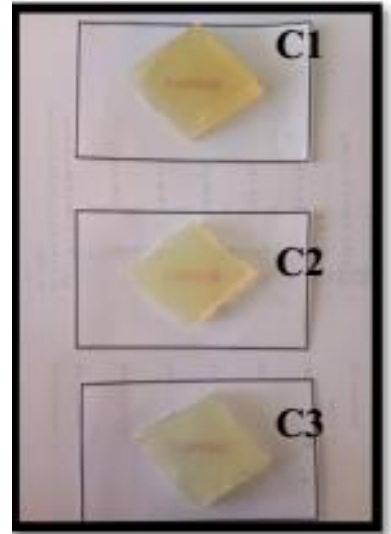

Formula C

Gambar 1. Hasil uji transparansi sediaan sabun padat transparan

Keterangan :

Formula A = Konsentrasi sukrosa 11\%

Formula B = Konsentrasi sukrosa $13 \%$

Formula $\mathrm{C}=$ Konsentrasi sukrosa $15 \%$

Berdasarkan hasil pengujian transparansi sediaan sabun padat transparan minyak sereh wangi diperoleh konsentrasi sukrosa yang optimum yaitu
Formula C penggunaan konsentrasi sukrosa $15 \%$. Hal ini berdasarkan pada tingkat keterbacaan huruf maupun tulisan dari balik sediaan sabun 
transparan, sehingga semakin meningkatnya konsentrasi sukrosa yang digunakan berbanding lurus terhadap tingkat transparansi sediaan sabun padat.

\section{KESIMPULAN}

Berdasarkan hasil tersebut dapat disimpulkan bahwa :

1. Konsentrasi optimum sukrosa yang digunakan dalam sediaan sabun padat transparan minyak sereh wangi adalah $15 \%$ yaitu formula $\mathrm{C}$.

2. Sediaan sabun padat transparan minyak sereh wangi stabil secara fisik dalam dalam $\mathrm{pH}$, ketinggian busa dan homogenitas.

\section{UCAPAN TERIMA KASIH}

Ucapan terima kasih kami berikan kepada Program Studi Farmasi STIKES Mandala Waluya Kendari yang telah membantu dalam penelitian ini.

\section{DAFTAR PUSTAKA}

Bota, W., Martosupono, M., Rondonuwu, F. S., Satya, K., Salatiga, W., Studi, P., Sains, F.-F., Matematika, D., Kristen, U., \& Wacana, S. (2015). Potensi Senyawa Minyak Sereh Wangi (Citronella Oil) Dari Tumbuhan Cymbopogon nardus L. Sebagai Agen Antibakteri. In Prosiding Semnastek (Vol. o, Issue o). https://jurnal.umj.ac.id/index.php/sem nastek/article/view/548

Hardian, K., Ali, A., Teknologi Pertanian, J., Pertanian, F., \& Riau, U. (2014). Quality Evaluation Of Solid Transparent Soap From Used Cooking Oil With The Addition Of Sls (Sodium Lauryl Sulfate) And Sucrose. In Universitas Riau Jom Faperta (Vol. 1, Issue 2). https://jom.unri.ac.id/index.php/JOMF APERTA/article/view/3558

Hernani, Bunasor, T. K., \& Fitriati. (2010). Formula Sabun Transparan Antijamur Dengan Bahan Aktif Ekstrak Lengkuas (Alpinia galanga L.Swartz.). Buletin Penelitian Tanaman Rempah Dan Obat. http://ejurnal.litbang.pertanian.go.id/in dex.php/bultro/article/view/1876

Pratiwi, F. N. (2015). Pengaruh minyak jahe sebagai fragrance oil terhadap sifat fisik sabun batang transparan minyak jahe - USD Repository [Universitas Sanata Dharma]. https://repository.usd.ac.id/601/ Pratiwi, R., \& Andiyani, L. S. (2014). Pabrik Sabun Transparan Beraroma Terapi Dari Minyak Jarak Dengan Proses Saponifikasi Trigliserida Secara Kontinyu. Presentation of Chemical Engineering, RSK 668.12 Pra p, 2014. http://digilib.its.ac.id/ITS-paper23021140004040/30227

Priani, S. E., \& Lukmayani, Y. (2010). Pembuatan Sabun Transparan Berbahan Dasar Minyak Jelantah serta Hasil Uji Iritasinya Pada Kelinci. Pros. SNaPP Sains Dan Teknologi, 36-53.

http://proceeding.unisba.ac.id/index.ph p/sains_teknologi/article/view/837

Rita, W. S., Vinapriliani, N. P. E., \& Gunawan, Iw. G. (2018). Formulasi Sediaan Sabun Padat Minyak Atsiri Serai Dapur (Cymbopogon citratus DC.) Sebagai Antibakteri Terhadap Escherichia coli Dan Staphylococcus aureus. Cakra Kimia (Indonesian E-Journal of Applied Chemistry, 6(2), 152-160.

Riyanta, A. Bu., \& Nurniswati. (2016). Adsorpsi Minyak Jelantah Menggunakan Karbon Aktif Dan Serbuk Kopi Pada Pembuatan Sabun Padat Ramah Lingkungan. SENIT 2016.

Sasongko, H., \& Mumpuni, A. S. (2017). Pengaruh penambahan sukrosa terhadap mutu sabun transparan dari ekstrak etanol herba pegagan (Centella asiatica L.). Pharmaciana, 7(1), 71. https://doi.org/10.12928/pharmaciana. v7i1.5795

Septiani, S., Wathoni, N., \& Mita, S. R. (2011). Pembuatan Sabun Transparan Aromaterapi Minyak Atsiri Akar Wangi (Chrysopogon zizanioides ( L.) Roberty (Vol. 1, Issue 1). Universitas Pakuan Bogor.

Setyoningrum, E. N. (2010). Optimasi Formula Sabun Transparan Dengan Fase Minyak Virgin Coconut Oil dan Surfaktan Cocoamidropyl Betaine, Aplikasi Desain Faktorial [Universitas Sanata Dharma]. https://repository.usd.ac.id/1736o/2/o6 8114174_Full.pdf 